\title{
How Much Sport is there in Sport Physiology? Practice and Ideas in the Stockholm School of Physiology at GCl, 1941-1969.
}

By: Daniel Svensson, PhD Student, Division of History of Science, Technology and Environment, KTH Royal Institute of Technology, Stockholm

This is an Accepted Manuscript of an article published by Taylor \& Francis in The International Journal of the History of Sport on May $23^{\text {rd }} 2013$, available online:

http://dx.doi.org/10.1080/09523367.2013.784274

\begin{abstract}
:
The physiology research at the Royal Central Institute of Gymnastics (Swedish acronym: GCI) in Stockholm was never primarily focused on sports, but has made significant contributions to sport and exercise physiology. Changing ideas about the human body (from form to motor) during the early $20^{\text {th }}$ century led to criticism towards the posture-oriented Ling gymnastics. The rationalization movement of the 1930s and onwards also paved the way for a rationalistic physiology research. $\mathrm{GCl}$ recruited Eric Hohwü Christensen (1904-96) from Copenhagen for the new position as professor in physiology in 1941. Christensen built his research program on the ideas of the Copenhagen School, focusing on basic research, bodily limits and rationalization of exercise. The majority of research at $\mathrm{GCl}$ focused on basic physiology and the main goal was to rationalize the exercise of the entire population, which was in line with the ambitions of the emerging Swedish welfare state. But applications in elite sports became a claim to fame for $\mathrm{GCl}$ through names like Per-Olof Åstrand and Bengt Saltin. This article aims at showing how the research program was outlined during Christensen's professorship, 1941-1969. How does a scientific environment focused on basic, physiological research become famous for its impact in sports?
\end{abstract}

\section{Keywords:}

Rational training, exercise physiology, Eric Hohwü Christensen, GCl, Sweden, welfare state

\section{Introduction}

Today, the role of science in athletic exercise and performance is obvious. And sports science is an academic field of its own, with specialized researchers devoted to enhancing the performance, health and fitness of (elite) athletes. It would be easy to understand earlier sport science the same way. But when physiologically inspired training methods arose in Scandinavia in the 1950s, they were not the result of research focused mainly on elite sports. Rather, applications of physiological research in elite sports were a side effect of a larger goal - to rationalize the physical education and training of the entire population. This article is an attempt to outline the formation of the physiological research program at The Royal Central Institute of Gymnastics (Swedish acronym: $\mathrm{GCl}$ ) in Stockholm from its start in the early 1940s and up to 1969, when Eric Hohwü Christensen retired. ${ }^{1}$ This scientific milieu became very important for sports, not least cross country skiing, in Sweden and 
internationally. But I will argue that elite sports were not the main interest of the $\mathrm{GCl}$ physiologists and that they never identified themselves as sport scientists. Rather, their focus was the intrinsic value of physiology as basic science. And in terms of applied research, physical education, work physiology and fitness training of the masses were more important than enhancing the performance of elite athletes. Why, then, have physiologists like Per-Olof Åstrand and Bengt Saltin become worldknown as sport scientists? To answer that, we should look at the formation of Swedish exercise physiology and its research program. The physiological research at $\mathrm{GCl}$ was shaped around a tension between basic and applied research, and this tension will be an important theme in my article. I will also, to some extent, try to understand the research at $\mathrm{GCl}$ in relation to the context of the emerging Swedish welfare state.

Some (but surprisingly little) research has been done when it comes to the history of sport science. In the Swedish context, the history of training methods in (middle distance) running has been examined. ${ }^{2} \mathrm{GCl}$ and its physiological research have been described by former and current employees. ${ }^{3}$ Internationally, there are a number of studies that has contributed to the field. The examples listed in the note below reflect the importance of the U.S., DDR and a number of WestEuropean countries in sport and exercise physiology. ${ }^{4}$ Regarding the Danish physiology, which is an important reference point in this article, some research has been done. ${ }^{56} \mathrm{My}$ article can contribute to further the knowledge about how sport science actually was conducted before it became a field of its own. This article is part of a larger research project, aimed at studying the history and rationalization of training in cross country skiing. The meeting between scientific and experiential knowledge regarding training led to new methods and $\mathrm{GCl}$ was a major contributor of scientific knowledge in this development. I will build this article mainly on the articles written by $\mathrm{GCl}$ physiologists, but also on personal interviews, archive material and earlier research.

\section{The rise of Swedish exercise physiology - Importing the Copenhagen school to GCI}

Ironically, the history of Swedish exercise physiology starts at the center of the Ling gymnastics, the regime of physical education that were to be replaced by sports during the $20^{\text {th }}$ century. $\mathrm{GCl}$ was created by P.H. Ling in 1813, and became the flagship of his ambitions to strengthen the Swedish people (for military, aesthetic and nationalistic purposes) by means of his gymnastic system. $\mathrm{GCl}$ has since then had its main task in educating physical education teachers. It is a fairly small university college (about 650 students), situated next to the 1912 Olympic Stadium in Stockholm. Until the 1930s, GCl was firmly rooted in the Ling tradition. Ling and his disciples had claimed that their gymnastic system was built on scientific ground, but during the first decades of the twentieth century this had been put into question, not least by Danish physiologists like Johannes Lindhard and Nobel Prize laureate August Krogh. At this time, Copenhagen was a world leading milieu for physiological research on work and athletic exercise. Johannes Lindhard and a few of his most promising students (among them Erik Hohwü Christensen) was the core of a direction of research that has been named both the Lindhard School and the Copenhagen School. Their research was focused on questions about the physiological limits of human physical performance, why and how it was limited and if those limits could be moved. The base of the research was methods from natural sciences, to ensure the validity of the results. ${ }^{7}$ Lindhard's most prominent work consisted almost exclusively of basic research around these questions and Christensen himself pointed out the same questions when 
asked about his research program towards the end of his life. ${ }^{8}$ Lindhard represented a similar position in Denmark as Christensen came to do in Sweden. His primary interest was scientific scrutiny of physical exercise and since Ling gymnastics had almost as high status in Denmark as in Sweden, it became subject of much of Lindhard's critique. He stressed the importance of the laboratory and the scientific results gathered there, while he rejected the knowledge claims of tradition and experience. According to Lindhard, science and practice should be separated and practice should build on scientific results, not on experience. ${ }^{9}$ His reputation and impact were furthered as he teamed up with August Krogh from the department of zoo physiology at University of Copenhagen. ${ }^{10}$ Lindhard's research was motivated by an ambition to rationalize physical exercise and education. In this strive he found himself in conflict with the broadly supported Ling gymnastics in Denmark. Christensen studied geology, geography and gymnastics at the University of Copenhagen. After his graduation he started working as an assistant at Lindhard's laboratory in Copenhagen. Along with his former student colleagues Erling Asmussen and Marius Nielsen, Christensen would have a great impact on physiology. While still working under Lindhard, he did research mainly on work physiology, focusing on metabolism, body temperature, respiration and heart-rate. This early research was the basis for Christensen's doctoral dissertation, and an important intellectual heritage that would be brought along to Stockholm later on. ${ }^{11}$

Lindhard initiated the cooperation with Krogh and got the former to include physical exercise as a factor in his basic research on respiration. He was also the more ideological of the two, with detailed visions of a bourgeois social order in which stability and strong, hard-working citizens were an integral part. ${ }^{12}$ Krogh was never primarily interested in exercise physiology, but his ongoing research and international credibility was a perfect match for Lindhard's agenda. The emphasis on scientific methods was a common trait for Lindhard and Krogh, and a crucial one as well. There has been an epistemological divide between scientific and experiential knowledge within the field of exercise physiology and this has become evident when scientific training methods collide with traditional, experiential ways of the athletes. Lindhard stressed the importance of physiology as a theoretical base for gymnastics, and outlined a both a general and a special theory of gymnastics to fill the need. ${ }^{13}$ The general theory was focused on how physiology should be applied in gymnastics, while the special theory outlined the theoretical base of gymnastic movement. Even though he certainly put some effort into these theories of gymnastics, Lindhard's own research was more basic than applied. ${ }^{14}$

Christensen eventually brought much of this agenda to Sweden and $\mathrm{GCl}$, even though the conservatism in time was replaced by a more collectivistic, welfare-oriented approach. At first, the scientific program of the Danish Copenhagen School had a hard time getting hold on GCl. Already in 1910 , a committee was formed to work for the reformation of $\mathrm{GCl}$. Resistance from staff at $\mathrm{GCl}$ and others faithful to the Ling gymnastics delayed the process. Among those who intensively debated against physiology at $\mathrm{GCl}$ were Patrik Haglund and Gunnar Frostell. Both were orthopedists, doctors and physical education teachers, educated at $\mathrm{GCl}$. In the debate about the future orientation of $\mathrm{GCl}$, Haglund and Frostell backed Ling gymnastics and orthopedics over physiology and sports. ${ }^{15}$ In this, they had support from a few other physical education teachers at $\mathrm{GCl} .{ }^{16}$ This resistance from orthopedists and Ling-inspired physical education teachers delayed the reformation process at $\mathrm{GCl}$. Not until 1938the Swedish parliament unanimously passed the proposition of a professor's chair in physiology at $\mathrm{GCl}$. The professor's chair had been heavily supported by all refereeing organizations in the governmental investigation of $1926 .{ }^{17}$ Given the inert nature of such investigations and decision 
processes, the broad support expressed in 1926 was not fully exploited until 1938. The appointment committee of the professor's chair consisted of Johannes Lindhard, Ernst Abramson and Torsten Thunberg. Lindhard naturally favored Christensen, and both Abramson and Thunberg were physiologists. Abramson was particularly engaged in the debate about physiology and sports. Building on the works of British physiologist A.V Hill, Abramson had compared work and sport physiology and proposed that athlete should follow rational training methods. ${ }^{18} \mathrm{He}$ was also during the period 1924-1936 a member of the board of the Swedish Sports Confederation and at times a fierce critic of Ling gymnastics. ${ }^{19}$ Given the above, it came as no surprise when the appointment committee was in agreement that Christensen should be named professor of physiology at $\mathrm{GCl}{ }^{20}$

As for the directory of $\mathrm{GCl}$, who also had a say in the matter, it was in the 1930 s made up by people who were very much in favor of physiology and of Eric Hohwü Christensen. Above mentioned Abramson and another physiologist, Göran Liljestrand, are two examples. Liljestrand had even worked together with Lindhard on several occasions. ${ }^{21}$ If Sweden had been the role model for Denmark in the $19^{\text {th }}$ century, with Ling gymnastics as the main export, in the1940s the situation was now the opposite. Denmark's physiological research and its influence over physical education and sports inspired Swedish physiologists and was used as a good example by the $\mathrm{GCl}$ directory in the process that eventually led to the appointment of Christensen. ${ }^{22}$ The unanimous decision of the Swedish parliament was, given the composition of the $\mathrm{GCl}$ directorate, the appointment committee and the favorable statements by the refereeing institutions, more of a formality.

Backed by the decision of the parliament and by a strong will to focus more on research related to endurance, respiration and circulation, $\mathrm{GCl}$ appointed the Danish physiologist Erik Howhü Christensen for the newly founded professorship in physiology in 1941. This was controversial, as some of the staff at $\mathrm{GCl}$ still ranked the Ling gymnastic system as the primary tool for physical education. There were suspicions and even conflict between gymnastics and sports in the larger context in Sweden, Denmark and other parts of Europe, but at $\mathrm{GCl}$ these potential conflicts were not allowed to evolve into any major problems during Christensen's time as professor. ${ }^{23}$ The appointment of Christensen aimed at reforming the prevailing gymnastic system and make way for a more rational, scientific and endurance-based approach. The strong mandate he had for doing this seems to have quenched any fatal conflicts between him and the gymnastic teachers. $\mathrm{GCl}$ had a mission to educate physical education teachers for bot educational and military purposes, and both staff and students were to a large extent militaries. During the 1940s, apart from the department of physiology, $\mathrm{GCl}$ consisted of gymnastic teachers and students. The only major field of research was physiology (and some minor studies in biomechanics), and it would remain like this until the $1980 \mathrm{~s}^{24}$

\section{Advocate of rationality - Christensen's program takes form}

The word rational (rationell in Swedish) is important here. It entered the Swedish language in the late $18^{\text {th }}$ century, and was at an early stage connected to scientific or at least systematic knowledge. Both Ling, who at least rhetorically recognized the importance of science for his gymnastic system, and Christensen, who dismissed Swedish gymnastics as unscientific and in many ways irrational, claimed to be advocates of rationality. In Ling's gymnastic system, rationality was a training that strengthened the body in a symmetrical way. Good posture and discipline were other key ingredients. ${ }^{25}$ 
For Christensen however, this was less important. His focus was instead the intrinsic value of basic research. As for applied science, he was more interested in maximizing the physical capacity of the population and rationalizing the physical education and exercise. In this, Christensen agreed with Lindhard and the others who had been involved in the appointment procedure. Lindhard and Christensen (and Christensen's upcoming recruits at $\mathrm{GCl}$ ) were part of a larger change in the understanding of the human body. During large parts of the $19^{\text {th }}$ century and especially in gymnastics, the body had been understood as a figure or a form, with good posture as an important ingredient. But in the first half of the $20^{\text {th }}$ century, this began to change. In line with the increasing strive for rationalization and effectiveness in industry, society and sport, the body was perceived more as a motor, and energy consumption and endurance became the primary way to measure the quality of a body. ${ }^{26}$ This also led to a decline in the tendency to see the body as a holistic unit. In short, the body went from repressed and shaped by formative gymnastics to a productive unit that could be trained for higher effect and increased performance. Energy was to be converted to labor by the human motor, and physiology was one of the sciences that approached this problem. ${ }^{27}$ The leading physiologist at the time, A. V. Hill, talked about the athlete as an "extraordinary machine". ${ }^{28}$ The motor or machine metaphors were accompanied by a new focus on enhancing human performance and potential, rather than just putting it to the best and most aesthetic use. ${ }^{29}$ The motor metaphor and the increasing attention paid to energy issues during physical activity were related, and there were several publications by physiologists already in the $19^{\text {th }}$ century disucussing the issue. ${ }^{30}$ In line with the above, rational training for Christensen meant focusing on increasing endurance, circulation and respiration rather than the aesthetic form of Ling gymnastics. Michel Foucault has shown that while the old powers used repression as the main form of control, this was not enough for the modern Western powers. They needed to be more productive and take control over life in as many ways as possible. ${ }^{31}$ Physiology, perhaps better than most other sciences, can contribute to bio-power as described by Foucault.

My conclusion is that this shifting of power strategies aligns with the fall of traditional Ling gymnastics and the rise of athletic training in its modern form. Earlier research suggests that Ling gymnastics was based on posture and on orthopedics, while physiology was more focused on the moving body, and thus leaned towards sports rather than Ling gymnastics. Sports were the field where the bodily motor was put to the test in the most demanding ways. ${ }^{32}$ Given the above mentioned interest in the moving body, physiologists at GCl during the period 1941-1969, like Åstrand, Saltin and Björn Ekblom, had an interest in sports as a means to test their scientific theories and results in action. Ling gymnastics were not as interesting for physiological studies due to its rather static and posture-focused exercises. The $\mathrm{GCl}$ physiologists were important proponents of the shifting in ideas about the human body. They focused more on endurance than on posture, and argued for endurance sports to replace Ling gymnastics in physical education. ${ }^{33}$ In conclusion, the former hegemony of gymnastics and aesthetics was during the course of the 1940s replaced by a new dynamic duo: sports and physiology. The $\mathrm{GCl}$ physiologists under Christensen's reign, through their basic research and public communication of their results, were integral parts of this change. In the 1962 curriculum for basic education, the shift from form to motor and from aesthetics to endurance was a clear fact. ${ }^{34}$

\section{Rational exercise - one aspect of the Swedish welfare state project}


Sports and physiology at $\mathrm{GCl}$ gained momentum in a time of heavy social change. Ideas about rationalization during the 1930s and 1940s were not isolated to the field of gymnastics. On the contrary, physiological research could be applied in the military service, in the factories etcetera. In Sweden and elsewhere in the industrialized world, researchers, politicians and other interested parties were searching for the most effective and rational way to reproduce, eat, exercise, cook, build cars, etcetera. In the fields of food, industry, military and sports this strive for rationalization was evident and, unsurprisingly, all of these fields turned to the physiological department at $\mathrm{GCl}$ for scientific guidance. ${ }^{35}$ And even though scientific management and rationalization of industry was hardly a socialist idea, the concept was intensively used in the Swedish context even as the Social Democratic Party rose to power in the early 1930s. Some resisted the rationalization altogether. But rationalization was conceived by many as a necessary development, given that the profits were used for the good of the workers and the welfare state society that was being built. ${ }^{36}$ There was, then, clearly a connection between the emerging Swedish welfare state and the ambition to rationalize life of the Swedish people. A rational way of exercise and physical education was one important factor in this strife. ${ }^{37}$ To ensure welfare for all, the population had to be as young, healthy, productive and effective as possible. There are numerous references to economic advantages with a rational training for the entire population, for example when Per-Olof Åstrand proposed regular exercise for elders. ${ }^{38}$ Rational training for everyone and rationalization in general was at the core of the Swedish welfare state. Practically every aspect of life was at some point subject to scientific analysis. The new social politics aimed not only for the traditional targets of welfare - the old, sick and needing - but also to the productive part of the population. ${ }^{39}$ This seems to be a crucial factor in the increasing focus on physical education and training. With effective and scientifically based training methods, even an already productive citizen could improve. Much as in the food industry, many interested parties combined their efforts to rationalize the whole field of exercise. The strife for economic growth and development seem to unite different actors in different fields in similar ways. In the frozen food industry, different actors (scientists, corporations, authorities) cooperated to establish freezing technology and thus rationalize fishing, food industry and further the industrialization of remote parts of the country. ${ }^{40}$ In athletics, it was scientists, authorities, athletic organizations and producers of athletic equipment that had a common interest to develop effective training methods that could appeal to large groups of the population. Intersections between basic and applied research is relevant in both food and in sports. The rationality of modern man is the key to understanding both.

As Christensen laid out the plans for his institution in 1944, he stated that the role of training, gymnastics and athletics alike, was to create possibilities for the working population to make 'the work result the best possible, with the least possible wear ${ }^{41}$ Both the people and their society should be as healthy, effective and productive as possible - that was the main goal in Christensen's physiological research. For Christensen, Åstrand, Saltin and others who were to follow at $\mathrm{GCl}$, the possible advantages of a well-trained population were focused on the greater good of the people, the welfare system and sometimes, as with Åstrand, on the individual work experience and spare time meaningfulness of the citizen. ${ }^{42} \mathrm{It}$ is interesting to compare the rationalistic attempts in Sweden with other, less welfare-oriented societies. While the rationalization movements in countries like the US or the UK were to a notable extent built on conservative, tayloristic ideals, this was not the case in Sweden. Taylorism did not fall in well with the strong Swedish unions and worker's movement and therefore never gained the same major influence as in many other countries. ${ }^{43}$ Instead, economic growth and a more efficient population were built on principles of equality, and cooperation 
between different interest groups. The rational exercise built on $\mathrm{GCl}$ physiology research fit well into the Swedish version of rationalization. $\mathrm{GCl}$ physiologists pointed to the possible wins of the individual, who by rational exercise could improve endurance and minimize fatigue. ${ }^{44}$ In a similar manner, the Swedish Social Democratic Party and labor unions saw rationalization as a means to enable social reformations. ${ }^{45}$ So it seems that a rational, physiology-based approach (to training, industrial work etcetera) can and has been used for very different political agendas, from Tayloristic capitalism to the mix-economy welfare state of $20^{\text {th }}$ century Sweden. There were also other examples in Europe during the 1940s and 1950s where systematic, rational training for workers was on the agenda. ${ }^{46}$ The Swedish welfare state project was built on a rationalistic ideology, where numerous aspects of everyday life were to be improved by science and expertise, mainly for the good of society but also for the good of the individual citizen. ${ }^{47}$ It is not surprising to see that the welfare state was paralleled by an attempt to spread bodily welfare.

\section{Basic research, with societal applications}

I would argue that the model of research used by physiologists at GCl during the 1940s and 1950s was based on a conviction that practice should build on science. While reflective practice and experiential methods of training have been of great importance to the practitioners of sports, like the Swedish cross country skiers, scientists at GCl have rather been engaged in a form of what Donald $A$. Schön call a 'Positivist epistemology of practice'. The successful military research projects during World War II made way for a firm belief in scientific research as a base for professional practice. ${ }^{48}$ In the physiology department at $\mathrm{GCl}$ under Christensen, basic science was the core and applications in practice a way to raise funds, and to test theory in action.

Christensen was heavily influenced by the Copenhagen School in general and by Johannes Lindhard in particular. There is however a notable difference between Copenhagen and Stockholm regarding the formation of exercise physiology discipline. While Lindhard faced the task of establishing gymnastics as a discipline, Christensen was trying to reform or even replace gymnastics with physiology and rational training. ${ }^{49}$ This might explain in part why Christensen was more clearly focused on basic research. Together with the Lindhard, Christensen had begun research on muscular work, respiration and body temperature. ${ }^{50}$ This meant that his focus was basic research and not primarily applied physiology. Yet, Christensen's institution at GCI made significant contributions to applied physiology in both labor and sports. This may seem odd, but popularizing and applying the results of science were actually important parts of the Copenhagen School's scientific program. In addition, the society in which Christensen performed his research was increasingly relating science to practical, societal utility. ${ }^{51}$ Christensen may have been focusing primarily on basic research, but he had a strong interest in society and even considered the human body as an economic asset. In 1944, Christensen wrote: 'the employer as well as the worker should consider his health a part of society's capital' ${ }^{52}$ If the body is understood in this manner, then rational training would consist of basically anything that maximize human work capacity and minimize illness. That is, good stamina, endurance, strength and effective technique for the task at hand. Christensen's research during his first years as a professor in Stockholm reflects these interests well. But during the first years, the economy of the newly founded department of physiology was not good. Christensen himself was the only higher employee and when he wanted an additional assistant he actually had to cover the expenses out of 
his own salary. ${ }^{53}$ The facilities were not suitable for research and the department moved to new facilities in 1944. There were also some disagreements between Christensen and the director of $\mathrm{GCl}$, disagreements that dissolved when Christensen himself became director at $\mathrm{GCl}$ in 1946. As I described earlier, the directory at $\mathrm{GCl}$ supported Christensen. But the director, Adolf Johnson, was not as positive. Therefore Christensen sought to circumvent Johnson by asking for instructions directly from the directorate. ${ }^{54}$ This conflict is one of rather few that can be found, which indicates that Christensen had a strong mandate at $\mathrm{GCl}$ already from the start of his employment. The fact that Christensen, without much controversy, was named director in 1946 underlines this. These first years of lacking resources made physiological research hard to conduct. Instead, Christensen started out writing about the institution and formulating a research program.

The first article by Christensen during his time at GCl was published in Tidskrift i Gymnastik in 1943. The magazine was founded already in 1874 and was the member's journal for the Swedish society for physical education teachers and thus read by many who still had their loyalties with the Ling gymnastics. ${ }^{55}$ Christensen's first article is aimed at clarifying his own views and opinions about gymnastics and athletic training. According to Christensen, the purpose of all training should be to further 'a certain muscular strength and endurance'. He points out that Ling gymnastics does not necessarily accomplish this. ${ }^{56}$ As a remedy, Christensen calls for a larger part of running and ball sports in school gymnastics as well as in other training. Even though he doesn't use the word rational, it is clear that what is rational for Christensen is a scientifically based training where physical results are more important than aesthetics. Having laid out his own views, Christensen later in 1943 published a piece (in the same journal) about the new physiology department. The article points out diet, children's physiology and training as important fields of research. Christensen also criticizes Ling gymnastics for lacking in scientific arguments and encourages critical reviews of different theories and scientific data. This stands in sharp contrast to Ling gymnastics, where obedience and discipline were among the leading principles. Christensen's inclination for rationality is expressed in eloquent style, when he writes that the students should 'on a base as rational as possible, learn to hold on to that of the old which is good - not because it is old, but because it is good'. ${ }^{57}$ Tradition, ideology and norm - all of them had to give way for Christensen's rational approach. Even though these early articles are focused on children and school gymnastics, it is clear, at least in hindsight, that the rational ambition of an effective and scientifically based training could benefit not only children and workers but also elite athletes.

From Copenhagen, Christensen brought with him the ambition to rationalize physical exercise and education through physiological research and critical examination of the existing training regimes. This theoretical base of the GCl physiological research was, however, not enough. It had to be paired up with an institutional organization that allowed it to develop. Ling's gymnastic system had a strong emphasis on unity. All forms of gymnastics (most importantly aesthetic, military, pedagogic and physiotherapeutic) were originally of importance and therefore taught and conducted at GCI. But when the unity of the body came into question, due to a decline in the ideas about the body as a holistic and aesthetic unit, $\mathrm{GCl}$ fell apart. During the 20th century, a series of administrative decisions underlined the separation of body and soul. In 1934, the physiotherapy was separated from the other forms of gymnastics and partly moved to medical institutions in Stockholm. Military gymnastics were transferred to a military academy during the 1930s. ${ }^{58}$ In practice, the only forms of gymnastics still important at $\mathrm{GCl}$ were aesthetic and pedagogic gymnastics. With the aestheticism in decline and 
the pedagogic gymnastics under attack from physiologists, the road was paved for the rationalizing and laboratory-based physiologists.

\section{The research program during Christensen's reign}

GCl's physiology research went from practically non-existing to international acknowledgement between 1941 and 1969, when Erik Hohwü Christensen was professor of physiology at GCI. Important scientific results from $\mathrm{GCl}$ during this period include data on physical working capacity, high altitude training, maximal oxygen uptake, and carbohydrate diet effects on athletic performance. $\mathrm{GCl}$ researchers like Per-Olof Åstrand, Bengt Saltin and Björn Ekblom are well known around the world for their contribution to both physiology and sports. Their scientific results contributed to training methods used by many of Sweden's Olympic athletes during the 1960s and are still influencing training methods in many sports, not least endurance sports. ${ }^{59}$

In the early 1940s, GCl had a department of physiology up and running, but its main task was still to educate physical education teachers. In 1943, Christensen wrote an article about reforming the education for physical education teachers. By focusing more on pedagogic education, school gymnastics could be more efficient. With smaller classes (no more than 30 students at a time), more intense endurance training, and more surveillance, the effectiveness could be heightened. ${ }^{60}$ This echoes of what Foucault writes about surveillance and productivity being the core of the modern, productive powers of the Western world. ${ }^{61}$ If one accepts Foucault idea that repressive power to an increasing degree has been replaced by productive power, it is possible to view Christensen's argument as a call for the repressive Ling gymnastics to be replaced by a more productive training regime. Christensen's interest was mainly in athletics for the masses and he shunned elite sports. This gets all the more clear when he comments on the benefits of well-educated physical education teachers and trainers for the Swedish population. With Christensen:

Training would thereby more and more become a rational process, conducted after certain, as far as possible theoretically based principles, and various private tricks and superstition would disappear from the athletic arena. ${ }^{62}$

This was an outright attack on both Ling gymnastics and on experiential training methods. As for the Ling gymnastics, it was deemed unscientific and lacking the theoretical base that all training should be based upon. Experiential training, on the other hand, was for Christensen little more than superstitious and ineffective. This criticism anticipates an escalating conflict between experiential and scientific training that would become evident already in the 1950s, not least in the Swedish national cross country skiing team. Skepticism towards experiential methods was inherited from Lindhard, who like Christensen, Åstrand and Saltin held scientific, laboratory-based knowledge in higher esteem.

Christensen's own research can be characterized as diverse. He seems to have been more focused on promoting the department and his younger colleagues than publishing his own works. ${ }^{63}$ Apart from the above-mentioned popular writings, a number of articles were published in peer-reviewed journals. Among these were articles about anaerobical work and intermittent or continuous work, typically neither work- nor sport related in any explicit way ${ }^{64}$ If applications are mentioned by 
Christensen, it is often possible applications in several areas, like in an article about intermittent muscular work from 1960:

By choosing longer periods, for example 2 to 3 min, one can obtain a high training effect also on respiration and circulation. This is of interest not only for the training of sportsmen, but also for rehabilitation of patients during the convalescent period, etc. ${ }^{65}$

The above is one of many examples of how the basic research of Christensen and his colleagues at $\mathrm{GCl}$ had potential to contribute in many fields of society, and their interest of providing a rational base for any physical activity.

Christensen's early articles were the starting point of a long line of publications from the department of physiology at GCl. During the period from 1941-1969 a total of 210 publications were published. Among these were nine dissertations and 82 scientific articles. The rest consisted mainly of popular books and articles in Swedish. Swedish physiologist Peter Schantz has analyzed the articles from GCl during Christensen's employment, and found a number of topics, among them many that relate to athletic training but also to labor and to military use. Schantz identified seven categories of articles respiration, circulation, muscles, temperature, biomechanics, children and other. More than 50 percent of the articles concern circulation. ${ }^{66}$ This shows a clear focus, which in part was due to a lack of funds. This limitation did however contribute to the expert knowledge and international reputation in some areas of physiological research.

As we have seen, the earliest articles were published in Swedish journals and contained little "hard science". That type of articles remained an important way to spread results to a broader public, but already in the 1940s the department of physiology at GCl started to publish internationally. Some articles written in German can be found in Arbeitsphysiologie (1928-1954).The publications in English were generally published in the established international journals, like Journal of Applied Physiology, and Acta Physiologica Scandinavica. These articles were focused on basic science, but often had the potential to contribute in training for athletes and others. ${ }^{67}$ The multitude of potential applications were explicitly pointed out in some cases, underlining the fact that Åstrand, Saltin et al. saw their research as important 'not only for the athletes but also for others who, for some reason, must engage in regular training to improve their physical condition' ${ }^{68}$ In the first years, most references point to Copenhagen School scientists or to colleagues at GCl. But during the 1950s there are an increasing number of references to the international journals mentioned above. British (often A.V.Hill), American and Scandinavian scientists are most commonly referred to. ${ }^{69}$ But in a typical article from $\mathrm{GCl}$, more than half of the notes referred to other $\mathrm{GCl}$ scientists. ${ }^{70}$ This could be seen as ignorant, but is rather an indication of the expertise that was piling at $\mathrm{GCl}$ in certain fields of physiological research.

Methods and tools for testing were important factors in the development of physiological research at $\mathrm{GCl}$. The low pressure chamber allowed for testing effects of high altitude. The bicycle ergometer designed by August Krogh and improved at $\mathrm{GCl}$ was another common way to test subjects. The ergometer allowed for fairly accurate comparison of different persons and changes over time. This relative accuracy attracted athletes, who did not have the same opportunities themselves. During the 1950s and 1960s, many Swedish and international elite athletes submitted themselves to testing on the bicycle ergometer. ${ }^{71}$ Typically, the scientists would gather a number of subjects of different physical status, from well trained to elite. Then these subjects were taken in to the laboratory were 
they underwent a specific regime of food, sleep and exercise, in order to produce comparable results. Such studies were conducted on Swedish elite skiers in the $1950 \mathrm{~s}^{72}{ }^{72}$ The common interest of the scientists (to test the whole variety of the population) and the athletes (to check their current status and hopefully acquire means to improve it) was crucial for this type of research. The differences in purpose did not create any major problems. In a study on circulatory and respiratory adaption to muscular work, interests met in a fruitful and typical way. In the study, paid for by the Swedish Sports Federation, GCl researchers (Christensen, Per-Olof Åstrand, Irma Åstrand and Rune Hedman, all of them physiologists) tested cross country skiers on bicycle ergometer. From the funder's point of view, the aim was to further the knowledge about the athlete's reactions and perhaps to find means of improvement. For the scientists however, the testing was mainly a way to confirm the validity of the bicycle ergometer tests. ${ }^{73}$ This is a typical and illustrative example of a study where interests combine and further each other. It is also worth noting the magnitude which is given to the laboratory and testing apparatus. Technical equipment to measure and improve the human motor - the shift from estheticism and posture to more energy-based views on the human body was a fact in the 1950s.

\section{International connections - both influenced and influential}

There were, obviously, other important centers of physiological research in the world. The Swedish development in exercise physiology was not unique. In Britain, Germany, USA, Denmark and a few other countries, exercise physiology was a well-established field. Why then did the research from $\mathrm{GCl}$ get such attention internationally? First, we should confirm that it did. A glance at the careers and international success of Åstrand and Saltin supports the claim to fame, but perhaps the best example is Textbook of Work Physiology, initiated by Christensen and written by Per-Olof Åstrand and three Norwegian physiologists. ${ }^{74}$ It has been printed in hundreds of thousands of copies and had an immense impact on education in physiology in Europe and North America. Besides that, Swedish physiologists were frequently referred to and invited to conferences in Europe and in the United States. ${ }^{75}$ In the field-overlooking Exercise Physiology. People and Ideas, Christensen, Åstrand and Saltin are frequently mentioned. ${ }^{76}$ By the 1970 s, Åstrand and Saltin were widely respected names in the world of physiology. ${ }^{77}$

Among the internationally renowned institutions and centers of physiological research, are A.V. Hill's team in Britain, Harvard with its fatigue laboratory, where Christensen and some of his colleagues from Copenhagen spent time in the 1930s, and Berkeley, where Åstrand stayed for six months in $1957 .{ }^{78}$ Especially Harvard Fatigue Laboratory, with its research focused on how to counter fatigue in industrial work, influenced Lindhard and thereafter Christensen. ${ }^{79}$ One might even say that the research to counter fatigue in industry, is a major part in what was transformed into applications in sport at $\mathrm{GCl}$ during the 1960 s and onwards. It is worth noting that the influences from the Copenhagen school, A. V. Hill and Harvard Fatigue Laboratory are linked in many ways. Krogh's research on respiration was later used by Hill when he developed his VO2 max test, a test that later was modified and used at $\mathrm{GCl} .{ }^{80}$ When Christensen was still an assistant of Lindhard in Copenhagen, he was sent to Britain to learn more about the testing methods of Hill. There was a written conversation between Lindhard and Hill about this in 1936, which indicates that they had some cooperation. ${ }^{81}$ There are also several articles and books written by Hill in the Christensen section of 
the archive at GIH. ${ }^{82}$ Hill was in the 1920s and 1930s perhaps the most renowned physiologist in the world, and his work on what caused muscular fatigue was well-known by scientists as well as others. ${ }^{83} \mathrm{~A}$ brief glance at the references in the articles from the $\mathrm{GCl}$ division of physiology 1941-1969 shows that while a large part of the references point to the Lindhard school or $\mathrm{GCl}$ itself, international influences where frequent as well. A.V. Hill along with David Bruce Dill of Harvard Fatigue Laboratory can be found among these references. ${ }^{84}$ That Harvard Fatigue Laboratory was an inspiration for both Lindhard and Christensen is clear. The tendency to involve athletes in the research at $\mathrm{GCl}$ was preceded both by Hill and at Harvard. ${ }^{85}$

Physiologists at $\mathrm{GCl}$ did research that further developed or sometimes outdated the research of Hill, Dill, and others. For example, Dill had been involved in testing footballers put on high carbohydrate diet. ${ }^{86}$ Similar research was later conducted at GCl, by Saltin, Hedman et al.. ${ }^{87}$ Dill had also worked on the composition of human sweat under different conditions, and Irma Åstrand used Dill's earlier research in her own works in the $1960 \mathrm{~s} .{ }^{88} \mathrm{~A}$.V. Hill had done extensive research on subjects like oxygen debt and lactic acid. ${ }^{89}$ Physiologists at GCl (Christensen, Åstrand, Åstrand, Saltin, and Karlsson, to name a few) later worked in similar areas as both Hill and Dill. ${ }^{90}$ And Hills research had originally inspired many of the scientists who founded the Harvard Fatigue Laboratory. ${ }^{91}$ The laboratory was until its closing in 1946 a primary center for physiologists, and the experiences from Harvard were vital for Christensen and many others. ${ }^{92}$

Apart from the international celebrities Hill, Dill, Lindhard and Krogh, there were additional contacts between Christensen and international physiologists. Christensen had contacts with Ernst Jokl in Kentucky. ${ }^{93}$ Jokl was in turn inspired by Hill, to the degree that he wrote a personal tribute to the British physiologist in $1980 .{ }^{94}$ There are also written correspondence between Christensen and C.H. McCloy, University of lowa, and Giuseppe La Cava, the Italian president of Federation International Medicine Sportive. ${ }^{95}$ International exchange of ideas in exercise physiology was already in the $1950 \mathrm{~s}$ a reality.

However, these centers of exercise physiology seem to have been engaged in a wider range of topics. The focus and specialization of $\mathrm{GCl}$ (mainly on issues of circulation and respiration, even if there were examples of research that fell outside of these categories) should be considered a crucial factor in their success. Another such factor is the successful recruitments that Christensen made during his professorship at $\mathrm{GCl}$.

Among the most prominent are Per-Olof Åstrand (born 1922), who came to the department of physiology at $\mathrm{GCl}$ in 1946 and thus became its first PhD student. He still keeps an office at $\mathrm{GIH}$. Bengt Saltin (born 1935) is another key recruitment, as well as Björn Ekblom (born 1938). All three had a background of training; Saltin and Ekblom were elite class in orienteering and Saltin later became chairman of the Swedish Orienteering Federation. In fact, an athletic backround has not been uncommon among leading physiologists. ${ }^{96}$ Other employees, like Paul Högberg and Gunnar Berggren (both physical education teachers with degrees from $\mathrm{GCl}$ ) were employed at the department for some years and became successful, but not mainly within the department. Both had a more pragmatic focus than Christensen, and their studies leaned towards applied sports physiology. One example is Paul Högberg's article about stride length and stride frequency from 1945, which is closer to applied science than any of Christensen's own articles. In the article, Högberg determines that the spontaneous stride length is the most effective. ${ }^{97}$ Articles like this gave $\mathrm{GCl}$ a good reputation in 
athletic community and paved the way for later contacts between athletes and scientists. This focus on athletics and sports separated Högberg and Berggren from Christensen, and that proved to be an obstacle in their careers as physiologists at $\mathrm{GCl}$. Both went on to other assignments after a few years, and Högberg actually became the new director at $\mathrm{GCl}$, thus replacing Christensen, who had resigned in protest against insufficient funding.

\section{Why physiology and sports?}

To answer the question as to why $\mathrm{GCl}$ physiologists started to do research related to training and sports, it is crucial to understand the context. As stated before, the rise of the welfare state and its need for productive, rational citizens worked in favor of physiology. And there was also a shared Nordic tendency to make sport a matter of public policy and increased interest and funding from the state. ${ }^{98}$ At the same time, the shift in how the human body was perceived (from form to motor) helped in making sports the primary means of physical exercise, at the expense of gymnastics. Finally, physiology and sports turned out to be mutually useful for each other, as the athletes needed scientific training methods to gain a competitive edge on the international scene, while the physiologists saw the athletic body as an interesting test subject. Earlier research has pointed out the importance of this win-win situation between athletes and scientists, and also pointed at the important role played by Eric Hohwü Christensen in the process of legitimizing scientific knowledge as a base for athletic exercise. ${ }^{99}$ My results underline these earlier findings.

As $\mathrm{GCl}$ was the core of the Swedish physical education, it was well within the job description to do basic research that could be used for effective, rational methods of training for the broader public and certainly for rationalizing the school gymnastics. Christensen, Åstrand et al took active part in the debate over which type of training that was most relevant for physical education, and eagerly promoted endurance training for this purpose. ${ }^{100}$ The physiologists were teaching at some courses in the $\mathrm{GCl}$ education for PE teachers, and therefore sports physiology had a direct purpose within the $\mathrm{GCl}$, as stated by Åstrand in $2012 .{ }^{101}$ Christensen was not pedagogically oriented in his own research, but he stressed the importance of rational training for school children in some of his articles. ${ }^{102}$ The rationalistic approach to exercise was well suited for the educational purpose. To scientifically scrutinize exercise was an import from Christensen's homeland Denmark. In this, there was always a potential for applications in elite sports. The scientific fascination in testing the full range of the population and that way validating the methods and seeing results in action, inspired people like Åstrand and Saltin to testing elite athletes. ${ }^{103}$ In the 1950 s and 1960 s, they tested many elite athletes in their laboratory at $\mathrm{GCl}$. But they also visited training camps of for example the Swedish national cross country skiing team to conduct ergometer testing. This was enabled by the high credibility of $\mathrm{GCl}$ physiologists, and by the fact that some of the scientists were themselves part of the athletic community. And Åstrand, in retrospective, holds the sport research in high esteem. ${ }^{104}$ It seems, however, as if though Christensen never accepted elite sports and applied science to take over at $\mathrm{GCl}$. If anyone leaned towards such a development, they did not stay long at the department. It is interesting to note how Christensen differs from other leading persons in the Swedish sports movement in the opinion of elite sports. Many leaders in Swedish sport praised the role of elite sports to inspire the masses to exercise. ${ }^{105}$ Christensen did not share this enthusiasm and stressed the importance of rational training for the broader public instead. Elite sports were mainly an 
experiment for Christensen and most of his colleagues - a way to test physiological theories and theses, ideally for the better of society as a whole, but never with any intrinsic value. Basic research was the focus. In this, Christensen was in line with the field of physiology at the time. ${ }^{106}$

Another factor that made way for sport physiology at $\mathrm{GCl}$ was that the Swedish Sports Confederation funded some studies. One example is a study about circulatory and respiratory response during heavy athletic exercise. ${ }^{107}$ Once again, it seems that the basic research was conducted independently but that interested parties had the possibility to finance additional studies focused on applications. Besides from the athletic community, the Swedish military and a number of private corporations paid for similar studies. At the time, the massive economy and commercialism of present day sports was yet to be realized. I see this fact as one of the major reason as to why sports science at $\mathrm{GCl}$ during the 1950s and 1960s never became a main subject.

Another incitement for research on sports was the fact that the athletes were a unique part of the population and thus valuable for science. In peace time, perhaps only sports could offer a welldefined group of healthy, athletic, young men. ${ }^{108}$ No wonder that the scientists wanted to study athletes. And remember the research program of the Copenhagen School, with its focus on man's physical limits - who better to study than those who came closest to those limits? The athletes also had an interest in submitting for tests. First, they got to know the hard facts about their own physical status. Second, they could use the results to adjust and improve their own training program. The organizations of sport also had hopes of furthering Sweden's ability to compete in the ever hardening competition on the international level, as they did in Britain and in many other countries. ${ }^{109}$ Given the context of rationalization, international competition and military arms race, physiology and sports were the perfect match at the time. It still is, in many ways, even though genetics and even robotics might have a say in the development of sport bodies in the future.

The changing perception of the body played a massive role in the formation of the physiological research at $\mathrm{GCl}$. The human body as a motor was the theoretic base of many projects, regarding circulation, energy consumption during exercise, and effective methods to improve fitness. But alone, this change in ideas about the human body would not have sufficed. It had to be paired with a context of rationality, which provided the incitements for research about how the bodily performance could be improved. Internal funds from $\mathrm{GCl}$ as well as external funding from interested parties in the Swedish society (for example military and industrial actors) enabled the physiology institution at $\mathrm{GCl}$ to actually succeed in their ambitions. Also, in the formation and relative success of Christensen's department at $\mathrm{GCl}$, the then apparent victory of scientific knowledge over experience played its part. The 'tacit knowledge' described by Michael Polanyi and the 'reflective practice' addressed by Donald A. Schön was yet to make an impact, and scientific knowledge had a very strong position. ${ }^{110}$ The focus on scientific knowledge rather than experience was a central part of the Copenhagen school and of Lindhard's philosophy. ${ }^{111}$ In short, the Copenhagen school's program was in line with the current epistemological fashion. The athletic community in Sweden was also, at this time, more closely tied to science than to experiential training methods. ${ }^{112}$ There had been a divide between experiential and scientifically inspired training methods for some time. In Sweden, Gösta Olander (experiential, natural training) and Gösse Holmér (scientific training) were the two main combatants. Similar debates raged elsewhere. But from the 1930s and onwards there was a more physiological approach to training in many countries. ${ }^{113}$ The battle was not just about science or experience, but also about physiology or style. In Sweden, Holmér showed interest in scientific 
methods, while Olander rather focused on natural training in the scenic surroundings of Vålådalen, where Swedish athletes like Sixten Jernberg, Assar Rönnlund, Gunder Hägg came for training camps. ${ }^{114}$ There were no formal contacts or cooperation between the Swedish trainers Olander and Holmér and the physiology department at $\mathrm{GCl}$. In this way, they differed from the German interval training proponents, Woldemar Gerschler and Herbert Reindell, who demonstrated the possibility of a close cooperation between athletes, trainers and scientists. ${ }^{115}$ I have found no explicit signs of any influence from Gerschler, Reindell, Olander or Holmér in the physiology of $\mathrm{GCl}$, but the success of Gerschler and Reindell may still have been an example to follow when contacts between $\mathrm{GCl}$ physiologists and Swedish elite athletes began in the 1950s (these contacts will be studied more closely in later stages of my project). ${ }^{116}$

\section{0 's - formalizing the relationship between sports and physiology}

In the 1960's, the department of physiology at GCl had become famous for its research both at home and abroad. The connection to (elite) sports was well established in Sweden, since many of Sweden's most successful Olympic athletes (for example Rönnlund, Jernberg, Rolf Rämgård, and Toini Gustafsson) had used methods designed by physiologists. At $\mathrm{GCl}$, Ling gymnastics were now a rare sight compared to sports. Given this context, the renovation of $\mathrm{GCl}$ in 1966 was quite logical. The name changed to GIH (The Swedish School of Sport and Health Sciences) which underlined the increasing importance of sports. And while it still had its primary task in educating physical education teachers, GIH was in practice made the main supplier of exercise and sports research in Sweden, thus formalizing what had already been the case for at least two decades. Close ties between $\mathrm{GCl}$ and the sports community was now a clear fact. For example, Paul Högberg, who had started out at Christensen's department, was now director of GIH. At the same time he was also on the board of several important sport organizations, including the Swedish Olympic Committee. ${ }^{117}$ By 1968 , the Swedish Sports Confederation actually funded two employments at $\mathrm{GIH}$, and also gave continuous support for the department of physiology during the 1960s. ${ }^{118}$ During the second half of the 1960s, there are examples of articles that are directly aimed at analyzing and improving the training of skiers or at least dealing with maximum performance. One article focused entirely on bare ground training methods for cross-country skiers, and pointed out the importance of high-intensity training. ${ }^{119}$ After the reorganization in 1966, the department of physiology at GIH continued to be an important actor in providing scientific grounds for new and improved training methods. The difference was that this was now a formalized part of its operation. Physiological research with bearing on exercise remained an important field, as did work physiology. Military aspects were on decline. Basic research was still the main activity, but many studies focused on applications in exercise and sports. Additional research could test the hypothesis that while sports where a spare time activity with no significant economy tied to it, sports research by necessity had to be conducted as a side effect of regular, 'useful' science. But parallel to the development of a massive sports economy, we have seen a specialization and increase of sport science. While economy was important during Christensen's time at $\mathrm{GCl}$, it was from the perspective of society and the possible benefits that a healthy, well-trained population could give. Today, sport organizations and clubs on national and international level have economic muscles to fund research themselves, focusing specifically on improving maximum performance or preventing injuries. 


\section{Conclusion}

There seems to be a discrepancy between how the work of Åstrand, Saltin et al is perceived by themselves and others. They themselves stress the importance of basic research. But the fact that Swedish athletes had great success when applying methods formulated by the $\mathrm{GCl}$ physiologists have opened up for a misinterpretation of their ambitions. The research program at $\mathrm{GCl}$ was formed around three key ingredients - the intrinsic value of basic physiological research, the interest of studying athletes as a unique test group, and finally, an external demand for improved athletic training methods, working methods and military training methods from the respective parts of Swedish society, in order to meet increasing international competition in the Cold War era and also to meet the demands for rationalization of the emerging welfare state. Even though the focus initially was more on school gymnastics than on sports, this changed gradually during the 1950s and 1960s. My conclusion is that while gymnastics was the main form of physical education, there was already a high grade of control within the system. But as gymnastics in Sweden failed to meet the challenge from sports like football, ice hockey, running and skiing, the need for control and rationality in sports became evident. Physiology was perhaps the most important means to achieve this control. In Britain, early responses to the Boer War and following discussions of national fitness did not evolve around elite sports, but rather around school sports and physical education. ${ }^{120}$ The connection between sports and national fitness, now rarely contested, was controversial during large parts of the $20^{\text {th }}$ century. This explains in part why Christensen was hesitant to discuss relations between sports and health, while his followers (in a pre-Twitter ${ }^{\circledast}$ sense of the word) Åstrand and Saltin gladly did. The political heritage from Lindhard was conservative, but Christensen, and certainly Åstrand and Saltin, were more focused on democratic access to rational training and exercise. This was, unsurprisingly, in line with the ambitions of the rationalizing welfare project of the Swedish Social Democratic Party. ${ }^{121}$ Indeed, rational training as understood by GCl physiologists, could improve the working man's experience. ${ }^{122}$

One thing remained constant at GCl during the years 1941-1969: research on sports and training were not the main target, but rather a fortunate possibility to raise some extra funds, gain credibility outside academia and test the results in action. Christensen saw certain sports as a better form of physical exercise than gymnastics, and he seems to have been aware of the fact that focus on questions about what limits maximum performance opened up for research about elite sports. ${ }^{123}$ But as long as he stayed at $\mathrm{GCl}$, Christensen's program of research ensured the focus on basic research and applications with broader ambitions than elite sports. Thanks to funding from the directory of the $\mathrm{GCl}$ (which included at times both Christensen himself and his former co-workers at the department of physiology), this focus on basic research were ensured. This is in line with what studies about Swedish research politics during the 1950s and 1960s has shown. It seems that basic research was assigned to the universities, while applied research was conducted at special research institutes. These were often partially financed by interested parties, such as industry or military. ${ }^{124}$ Since $\mathrm{GCl}$ at the time had more in common with a college university than with a privately funded research institute, basic research was the natural focus. Given the amateurism of sports in general and in Swedish sports in particular, it is only logical that the scientists, as well as some of the athletes they were testing, tended to see sports as a hobby, as Bengt Saltin stated in a recent interview. ${ }^{125}$ However sports-oriented their research might seem in the rear-view mirror, the $\mathrm{GCl}$ physiological 
department was built around the laboratory rather than the training field. The main ambition, according to Åstrand, was to determine what limits human work capacity. ${ }^{126}$ That does not rule out the possibility of a massive present day impact in sports. Just recently, Bengt Saltin was once again engaged by the Swedish Ski Association to help with physiological testing and expertise to further the performance of elite cross country skiers, regarding high altitude training to name one aspect. What was once basic research is now, it seems, just as basic in elite sports.

\section{Notes on Contributor}

Daniel Svensson is a PhD student at the Division of History of Science, Environment, and Technology at the Royal Institute of Technology (KTH) in Stockholm.

\section{Notes}

\footnotetext{
${ }^{1}$ From $1966 \mathrm{GCl}$ changed its name to GIH, acronym for Gymnastik- och idrottshögskolan (The Swedish School of Sport and Health Sciences).

${ }^{2}$ Yttergren, Träna är livet.

${ }^{3}$ Schantz, 'Om Lindhardskolan och dess betydelse i ett svenskt perspektiv', and Åstrand, 'Fysiologiska institutionens tillkomst och utveckling'.

${ }^{4}$ Krüger and Riordan, European Cultures in Sport. Berg and König, 'History of sports medicine in Germany with special reference to the university of Freiburg'. Roger and Terret, European Athletics. Mangan, 'Manufactured' Masculinity'. Heggie, A History of British Sport Medicine. Tipton, Exercise Physiology. People and Ideas. Berryman and Park, Sport and Exercise Science. Essays in the History of Sports Medicine. Rabinbach, The human motor. Mangan and Meinander, The Nordic World: Sport in Society.

${ }^{5}$ Asmussen, Gymnastikstudiet. Bonde and Frøslev Jensen, 'Gymnastics'.

${ }^{7}$ Saltin and Hellsten, 'The legacy of the Copenhagen School', 347-348.

${ }^{8}$ Schantz, 'Om Lindhardskolan', 148-150.

9 Bonde and Frøslev Jensen, 'Gymnastics', 1929.
} 
${ }^{10}$ Lindroth, Ling - från storhet till upplösning, 116-117.

${ }^{11}$ Asmussen, Gymnastikstudiet, 71, and Söderberg, Från gestalt till motor, 30.

${ }^{12}$ Bonde and Frøslev Jensen, 'Gymnastics', 1931-1934.

${ }^{13}$ Lindhard, Den specielle gymnastikteori, and Lindhard, Den almindelige gymnastikteori. There is also an

English edition: Lindhard, The Theory of Gymnastics.

${ }^{14}$ Söderberg, Från gestalt till motor, 26.

${ }^{15}$ Söderberg, Tre perspektiv på idrott och medicinvetenskap, 10-11, 22-23.

${ }^{16}$ Söderberg, Från gestalt till motor, 36.

${ }^{17}$ SOU (Swedish Governmental Investigations), 1926: 10, 21-24

${ }^{18}$ Söderberg, Från gestalt till motor, 34.

${ }^{19}$ Nationalencyklopedin, 'Ernst Abramson'

${ }^{20}$ Söderberg, Från gestalt till motor, 36-38.

${ }^{21}$ Schantz, 'Om Lindhardskolan och dess betydelse i ett svenskt perspektiv', 144.

${ }^{22}$ Schantz, 'Om Lindhardskolan', 142-143.

${ }^{23}$ Jørgensen. 'From Balck to Nurmi', 71-72.

${ }^{24} \mathrm{GIH}$, 'Från GCl till GIH - mer historia'.

${ }^{25}$ The ideology of Ling gymnastics has been studied in detail. Among the most important contributions are: Lindroth, Ling - från storhet till upplösning, and Ljunggren, Kroppens bildning. Linggymnastikens manlighetsprojekt 1790-1914.

${ }^{26}$ Söderberg, Från gestalt till motor, 37-38 et passim.

${ }^{27}$ Rabinbach, The human motor, $72-78$ et passim.

${ }^{28}$ Hoberman, Mortal Engines, 11.

${ }^{29}$ Beamish and Ritchie, 'From Fixed Capacities to Performance-Enhancement', 429.

${ }^{30}$ Johnson, Human performance, 63-65 et passim.

${ }^{31}$ Foucault, The Will to Knowledge, 138-139 et passim. See also: Foucault, Madness and Civilization.

${ }^{32}$ Lindroth, Ling - från storhet till upplösning, 98.

${ }^{33}$ Lundquist Wanneberg, Kroppens medborgarfostran, 134-142, 208-211.

${ }^{34}$ Lundquist Wanneberg, Kroppens medborgarfostran, 167.

${ }^{35}$ The Swedish rationalization movement has been studied in: De Geer, Rationaliseringsrörelsen i Sverige.

${ }^{36}$ Björck, Folkhemsbyggare, 127-133.

${ }^{37}$ Lundquist Wanneberg, Kroppens medborgarfostran, 33, 207, 216-218.

${ }^{38}$ Åstrand, Kondition och hälsa, 12, 34.

${ }^{39}$ Lövgren, Hemarbete som politik, 22-23.

${ }^{40}$ Finstad, Varme visjoner og frosne fremskritt, 229-236 et passim.

${ }^{41}$ Hohwü Christensen, Kroppsövningarnas fysiologi och hygien, 138 (my translation).

${ }^{42}$ Åstrand, Kondition och hälsa, 38-39.

${ }^{43}$ Taylorism in Sweden has been discussed by, among others: De Geer, Rationaliseringsrörelsen i Sverige, 37 et passim.

${ }^{44}$ Christensen, Kroppsövningarnas fysiologi och hygien, 121.

${ }^{45}$ De Geer, Rationaliseringsrörelsen i Sverige, 317-318, 358 et passim.

${ }^{46}$ Blondel and Terret, 'Towards an Internationalization of Workers' Training'.

${ }^{47}$ Hirdman, Att lägga livet till rätta, 176-187 et passim.

${ }^{48}$ Schön, The Reflective Practitioner, 37-39.

${ }^{49}$ Bonde and Frøslev Jensen, 'Gymnastics', 1936.

${ }^{50}$ Åstrand, 'Fysiologiska institutionens tillkomst och utveckling', 197-198.

${ }^{51}$ Nybom, Kunskap, politik, samhälle, 64-69

${ }^{52}$ Hohwü Christensen, Kroppsövningarnas fysiologi och hygien, 138 (my translation).

53 Åstrand, 'Fysiologiska institutionens tillkomst och utveckling', 200-202.

${ }^{54}$ Schantz, 'Om Lindhardskolan', 148.

${ }^{55}$ Nationalencyklopedin,'Tidskrift i gymnastik och idrott'.

${ }^{56}$ Hohwü Christensen, 'Gymnastiken och den allmänna träningen av organismen', 3-4, my translation.

${ }^{57}$ Hohwü Christensen, 'GCl:s fysiologiska institution', 49.

${ }^{58}$ Lindroth, Ling - från storhet till upplösning, 72-74.

${ }^{59}$ Some examples are hydration, high intensity interval training and carbohydrate loading; the latter used by Swedish skiers (most notably Karl-Åke Asph, Sixten Jernberg, Janne Stefansson, Assar Rönnlund and Sture 
Grahn) in the 1962 World Cup and the 1964 Olympics with good result. Åstrand, 'Fysiologiska institutionens tillkomst och utveckling', 230-231.

${ }^{60}$ Hohwü Christensen, 'Förslag till ny utbildningsplan för lärare i gymnastik, lek och idrott', 167-168 et passim.

${ }^{61}$ Foucault, The Will to Knowledge, 140-145.

${ }^{62}$ Hohwü Christensen, 'Förslag till ny utbildningsplan för lärare i gymnastik, lek och idrott', 178, my translation.

${ }^{63}$ Schantz, 'Om Lindhardskolan', 154.

${ }^{64}$ Exemplified by: Christensen and Högberg, 'The Efficiency of Anaerobical Work', Christensen, Hedman and Holmdahl, 'The Influence of Rest Pauses on Mechanical Efficiency', Christensen, Saltin and Hedman, 'Intermittent and Continuous Running'.

${ }^{65}$ Christensen et al., 'Intermittent Muscular Work', 452.

${ }^{66}$ Schantz, 'Om Lindhardskolan', 155.

${ }^{67}$ Åstrand and Saltin, 'Maximal oxygen uptake in athletes'. Saltin and Stenberg, 'Circulatory response to prolonged severe exercise'.

${ }^{68}$ Karlsson, Åstrand and Ekblom, 'Training of the oxygen transport system in man', 1065.

${ }^{69}$ Heggie, A History of British Sport Medicine, 101.

${ }^{70}$ Rodahl, Åstrand and Åstrand, 'Maximal heart rate during work in older men', 566.

${ }^{71}$ Åstrand, 'Fysiologiska institutionens tillkomst och utveckling', 230-231.

${ }^{72}$ Hedman, 'The available glycogen in man and the connection between rate of oxygen intake and carbohydrate use', 307-310, 319-320.

${ }^{73}$ Hedman et al., 'Circulatory and respiratory adaption to severe muscular work', 256-258.

${ }^{74}$ Dahl, Strømme, Rodahl, and Åstrand, Textbook of work physiology.

${ }^{75}$ Åstrand, 'Fysiologiska institutionens tillkomst och utveckling', 235-236.

${ }^{76}$ Tipton, Exercise Physiology, 497-510.

77 Johnson, Human performance, 115-117.

78 Åstrand, 'Fysiologiska institutionens tillkomst och utveckling', 215.

${ }^{79}$ Bonde and Frøslev Jensen, 'Gymnastics - an Emerging National University Discipline', 1936.

${ }^{80}$ Johnson, Human performance, 69-70.

${ }^{81} \mathrm{GIH}$ archive, written correspondence, copy of letter from A.V. Hill to Johannes Lindhard, June 10th 1936.

${ }^{82} \mathrm{GIH}$ archive, Christensen, books and re-prints.

${ }^{83}$ Wrynn, 'The Athlete in the Making', 129.

${ }^{84}$ One example can be found in: Asmussen, Nielsen and von Döbeln, 'Blood Lactate and Oxygen Debt After Exhaustive Work at Different Oxygen Tensions', 62.

${ }^{85}$ Wrynn, 'The Athlete in the Making', 128-130..

${ }^{86}$ Wrynn, 'The Athlete in the Making', 128.

${ }^{87}$ For example: Saltin et al., 'Diet, Muscle Glycogen and Physical Performance', and Hedman, 'The Available Glycogen in Man and the Connection between Rate of Oxygen Intake and Carbohydrate Usage'.

${ }^{88}$ Åstrand, 'Lactate Content in Sweat'.

${ }^{89}$ Heggie, A History of British Sport Medicine, 101.

${ }^{90}$ Åstrand and Saltin, ' Oxygen uptake during the first minutes of heavy muscular exercise', Åstrand and Saltin, 'Maximal oxygen uptake in athletes'.

${ }^{91}$ Beamish and Ritchie, 'From Fixed Capacities to Performance-Enhancement', 418-419.

${ }^{92}$ Johnson, Human performance, 100-103.

${ }^{93} \mathrm{GIH}$ archive, Department of Physiology, written correspondence 1954, letter from Ernst Jokl to Erik HohwüChristensen, November 22 $2^{\text {nd }}, 1954$.

${ }^{94}$ Jokl, 'Professor AV Hill, a Personal Tribute'.

${ }^{95} \mathrm{GIH}$ archive, Department of Physiology, written correspondence 1954 and 1955.

${ }^{96}$ Park, 'Physicians, Scientists, Exercise and Athletics', 16.

${ }^{97}$ Högberg, 'Undersökningar över steglängd och stegfrekvens vid löpning', 258-261 et passim.

${ }^{98}$ Norberg, 'A Mutual Dependency', 131-132.

${ }^{99}$ Yttergren, Träna är livet, 119-122.

${ }^{100}$ Lundqvist Wanneberg, Kroppens medborgarfostran, 134-142.

${ }^{101}$ Interview with Per-Olof Åstrand,February $3^{\mathrm{d}}, 2012$.

${ }^{102}$ Hohwü Christensen, 'Förslag till ny utbildningsplan för lärare i gymnastik, lek och idrott'.

${ }^{103}$ Interview with Bengt Saltin, February $13^{\text {th }}, 2012$.

${ }^{104}$ Interview with Per-Olof Åstrand, February 3 ${ }^{\mathrm{d}}, 2012$.

${ }^{105}$ Sandblad, Olympia och Valhalla, 346-347 et passim. 


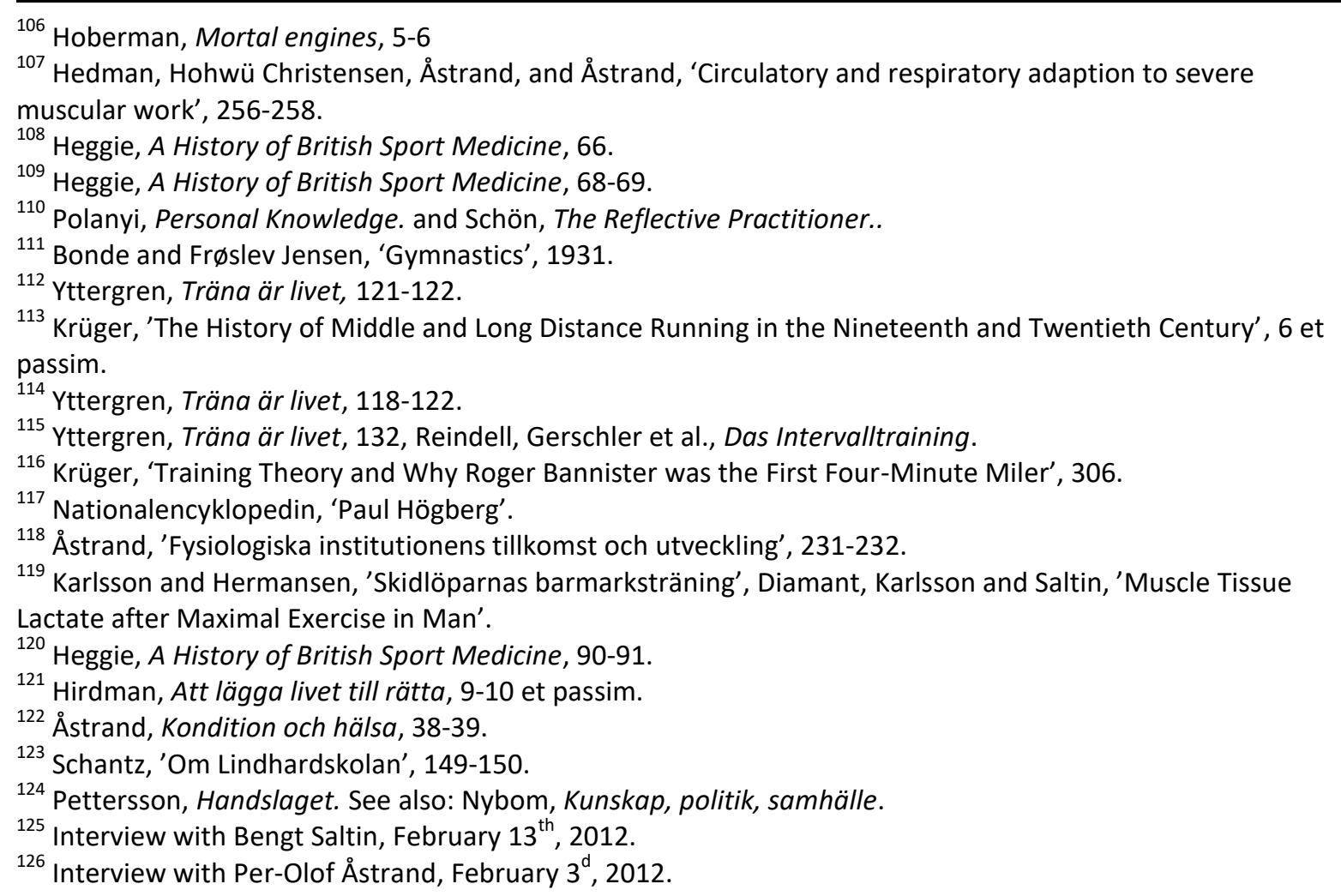

References (I have translated a few Swedish titles that might interest international readers)

Asmussen, Erling, Gymnastikstudiet og det Gymnastikteoretiske Laboratorium ved Københavns Universitet - Tilbageblik på Trekvart Århundredes Hændelser. Copenhagen: Idrættens Forskningsråd, 1988.

Asmussen, Erling, Nielsen, Marius, and von Döbeln, Wilhelm, 'Blood Lactate and Oxygen Debt After Exhaustive Work at Different Oxygen Tensions' in Acta Physiologica Scandinavica, vol. 15, issue 1, p. 57-62. Stockholm: The Scandinavian Physiological Society, 1957.

Beamish, Rob and Ritchie, lan, 'From Fixed Capacities to Performance-Enhancement' in Sport in History, issue 25:3, p. 412-433. Oxford: Routledge, 2005.

Berg , Aloys \& König, Daniel 'History of sports medicine in Germany with special reference to the university of Freiburg' in European Journal of Sport Science, issue 2:4, p. 1-7. Oxford: Routledge, 2002.

Berryman, Jack and Park, Roberta J., Sport and Exercise Science. Essays in the History of Sports Medicine. Champaign: University of Illinois Press, 1992.

Björck, Henrik, Folkhemsbyggare. Stockholm: Atlantis, 2008.

Bonde, Hans and Frøslev Jensen, Anders, 'Gymnastics - an Emerging National University Discipline Johannes Lindhard's Struggle to Institutionalise Gymnastics as a Subject at the University of Copenhagen 1909-1940' in The International Journal of the History of Sport, 2011, issue 28:14.

Oxford: Routledge, 2011. 
Dahl, Hans A., Strømme, Sigmund B., Rodahl, Kaare and Åstrand, Per-Olof, Textbook of Work Physiology. Champaign: Human Kinetics, 2003.

De Geer, Hans, Rationaliseringsrörelsen i Sverige: effektivitetsidéer och socialt ansvar under mellankrigstiden. English title: The rationalization movement in Sweden: efficiency programs and social responsibility in the interwar years. Stockholm: SNS, 1978.

Finstad, Terje, Varme visjoner og frosne fremskritt. Om fryseteknologi i Norge, ca. 1920 - 1965. Trondheim: Norges teknisk-naturvitenskapelige universitet, Institutt for tverrfaglige kulturstudier, 2011.

Foucault, Michel, The Will to Knowledge. The History of Sexuality, Volume 1. New York: Penguin Books, 1998.

Foucault, Michel, Madness and Civilization. New York: Routledge, 2001.

GIH archive, Archive for the Department of Physiology, GIH, Stockholm: Written correspondence 1954-1955, Christensen's collection of books and re-prints.

GIH, official webpage, February $21^{\text {st }}, 2013$, Lindroth, Jan, 'Från GCI till GIH - mer historia', <http://www.gih.se/200ar/GIHs-historia/Fran-GCI-till-GIH---mer-historia/>.

Hedman, Rune, 'The available glycogen in man and the connection between rate of oxygen intake and carbohydrate use' in Acta Physiologica Scandinavica, issue 40, 1957. Stockholm: The Scandinavian Physiological Society, 1957.

Hedman, Rune, Hohwü Christensen, Erik, Åstrand, Irma and Åstrand, Per-Olof, 'Circulatory and respiratory adaption to severe muscular work' in Acta Physiologica Scandinavica, issue 50, 1960. Stockholm: The Scandinavian Physiological Society, 1960.

Heggie, Vanessa, A History of British Sport Medicine. Manchester: Manchester University Press, 2011. Hirdman, Yvonne, Att lägga livet till rätta. Stockholm: Carlsson Bokförlag, 2010

Hoberman, John M., Mortal engines: the science of performance and the dehumanization of sport. Free Press, New York, 1992.

Hohwü Christensen, Erik, 'Gymnastiken och den allmänna träningen av organismen' in Tidskrift $i$ gymnastik, issue 1, 1943. Stockholm: Svenska Gymnastikläraresällskapet, 1943.

Hohwü Christensen, Erik, 'GCl:s fysiologiska institution' in Tidskrift i gymnastik, issue 3, 1943. Stockholm: Svenska Gymnastikläraresällskapet, 1943.

Hohwü Christensen, Erik, 'Förslag till ny utbildningsplan för lärare i gymnastik, lek och idrott' in Tidskrift i gymnastik, issue 10, 1943. Stockholm: Svenska Gymnastikläraresällskapet, 1943.

Hohwü Christensen, Eric, Kroppsövningarnas fysiologi och hygien. English title: The Physiology and Hygiene of Exercise. Stockholm: Bonniers, 1944.

Hohwü Christensen, Erik and Högberg, Paul, 'The Efficiency of Anaerobical Work', Arbeitsphysiologie, vol. 14 , issue 3,1950, p. 249-250. 
Hohwü Christensen, Erik, Hedman, Rune and Holmdahl, Inga, 'The Influence of Rest Pauses on Mechanical Efficiency', Acta Physiologica Scandinavica, issue 48, 1960, p. 443-447. Stockholm: The Scandinavian Physiological Society, 1960.

Hohwü Christensen, Erik, Saltin, Bengt and Hedman, Rune, 'Intermittent and Continuous Running' in Acta Physiologica Scandinavica, issue 50, 1960, p. 269-286. Stockholm: The Scandinavian Physiological Society, 1960.

Hohwü Christensen, Erik, Åstrand, Per-Olof, Åstrand, Irma and Hedman, Rune, 'Intermittent Muscular Work' in Acta Physiologica Scandinavica, issue 48, 1960, p. 448-453. Stockholm: The Scandinavian Physiological Society, 1960.

Högberg, Paul, 'Undersökningar över steglängd och stegfrekvens vid löpning' in Tidskrift i gymnastik, issue 12, 1945. Stockholm: Svenska Gymnastikläraresällskapet, 1945.

Johnson, Andi, Human Performance. An Etnographic and Historical Account of Exercise Physiology. Ann Arbor: Proquest, 2009.

Jokl, Ernst, 'Professor AV Hill, a Personal Tribute' in Journal of Sports Medicine and Physical Fitness, issue 20, p. 465-468, 1980.

Jørgensen, Per, 'From Balck to Nurmi: The Olympic Movement and the Nordic Nations' in Meinander, Henrik and Mangan, J.A. (ed.), The Nordic World. Sport in Society. London: Frank Cass, 1998.

Karlsson, Jan and Hermansen, Lars, 'Skidlöparnas barmarsträning: en fysiologisk analys' in Tidskrift i Gymnastik, issue 12, 1966. Stockholm: Svenska Gymnastikläraresällskapet, 1966.

Karlsson, Jan, Åstrand, Per-Olof and Ekblom, Björn, 'Training of the oxygen transport system in man', in Journal of Applied Physiology, 1967, issue 22:6, p. 1061-1065. The American Physiological Society, 1967.

Krüger, Arnd and Riordan, James (ed.), European Cultures in Sport. Examining the Nations and Regions. Bristol: Intellect, 2003.

Krüger, Arnd, 'The History of Middle and Long Distance Running in the Nineteenth and Twentieth Century' in Krüger, Arnd and Teja, Angela (ed.), La Comune Ereditá dello Sport in Europa: Atti del 1 Seminario Europeo di Storia dello Sport. Rome: CONI, 1997.

Krüger, Arnd, 'Training Theory and Why Roger Bannister was the First Four-Minute Miler' in Sport in History, issue 26:2, p. 305-324. Oxford: Routledge, 2006.

Lindhard, Johannes, Den specielle gymnastikteori. Copenhagen, 1914.

Lindhard, Johannes, Den almindelige gymnastikteori. Copenhagen: Larsens, 1919.

Lindhard, Johannes, The Theory of Gymnastics, London: Methuen, 1934.

Lindroth, Jan, Ling - från storhet till upplösning. Studier i svensk gymnastikhistoria 1800-1950.

Stockholm: Symposion, 2004. 
Ljunggren, Jens, Kroppens bildning. Linggymnastikens manlighetsprojekt 1790-1914. Stockholm: Symposion, 1999.

Lundquist Wanneberg, Pia, Kroppens medborgarfostran. Kropp, klass och genus i skolans fysiska fostran 1919-1962. Stockholm: Stockholms Universitet, 2004.

Lövgren, Britta, Hemarbete som politik. Diskussioner om hemarbete, Sverige 1930-40-talen, och tillkomsten av Hemmens forskningsinstitut. Stockholm: Almqvist \& Wiksell International, 1993.

Mangan, J.A., 'Manufactured' Masculinity. Making Imperial Manliness, Morality and Militarism. Oxford: Routledge, 2011.

Meinander, Henrik and Mangan, J.A. (ed.), The Nordic World: Sport in Society. London: Frank Cass Publishers, 1998.

Nationalencyklopedin, official website, August $13^{\text {th }} 2012$, 'Paul Högberg', $<$ www.ne.se/paulhögberg>.

Nationalencyklopedin, official website, September 30th 2012, 'Tidskrift i gymnastik och idrott' $<$ http://www.ne.se/tidskrift-i-gymnastik-och-idrott>.

Nationalencyklopedin, official website, February $14^{\text {th }}, 2013$, 'Ernst Abramson' $<$ http://www.ne.se./ernst-abramson>

Norberg, Johan R., 'A Mutual Dependency: Nordic Sports Organizations and the State' in Meinander, Henrik and Mangan, J.A. (ed.), The Nordic World: Sport in Society. London: Frank Cass Publishers, 1998.

Nybom, Thorsten, Kunskap, politik, samhälle: essäer om kunskapssyn, universitet och forskningspolitik 1900-2000. Hargshamn: Arete, 1997.

Park, 'Physicians, Scientists, Exercise and Athletics in Britain and America from the 1867 Boat Race to the Four-Minute Mile' in Sport in History, issue 31:1, p. 1-31. Oxford: Routledge, 2011.

Pettersson, Ingemar, Handslaget. Stockholm: KTH, , 2012.

Polanyi, Michael, Personal Knowledge. Towards a Post-Critical Philosphy. Chicago: University of Chicago Press, 1958.

Rabinbach, Anson, The Human Motor. Energy, Fatigue, and the Origins of Modernity. New York: Basic Books, 1990.

Reindell, Herbert, Gerschler, Woldemar et al., Das Intervalltraining: physiologische Grundlagen, praktische Anwendungen und Scädigungsmöglichkeiten. München: Barth, 1962.

Rodahl, Kaare, Åstrand, Irma and Åstrand, Per-Olof, 'Maximal heart rate during work in older men' in Journal of Applied Physiology, issue 14, 1959. Washington: American Physiological Society, 1959.

Roger, Anne and Terret, Thierry, European Athletics. A Continental History of Track and Field (1912 2010). Stuttgart: Neuer Sportverlag, 2011. 
Tipton, Charles M., (ed.), Exercise Physiology. People and Ideas. New York: Oxford University Press, 2003.

Saltin, Bengt and Hellsten, Ylva, 'The legacy of the Copenhagen School: in the footsteps of Lindhard and Krogh' in Acta Physiologica, 2010, issue 199. Stockholm: Scandinavian Physiological Society, 2010.

Saltin, Bengt, Bergström, Jonas, Hermansen, Lars, and Hultman, Eric, 'Diet, Muscle Glycogen and Physical Performance' in Acta Physiologica Scandinavica, 1967, issue 71, p. 140-150. Stockholm: The Scandinavian Physiological Society, 1967

Saltin, Bengt and Stenberg, Jesper, 'Circulatory response to prolonged severe exercise' in Journal of Applied Physiology, 1964, issue 19:5, p. 833-838. The American Physiological Society, 1964.

Sandblad, Henrik, Olympia och Valhalla. Idéhistoriska aspekter av den moderna idrottsrörelsens framväxt. English title: Sport and ideas. Aspects of the rise of the modern sport movement. Grillby: Lärdomshistoriska samfundet, 1985.

Schantz, Peter, 'Om Lindhardskolan och dess betydelse i ett svenskt perspektiv' in Forskning $i$ bevaegelse. Et nyt forskningsfelt i et 100-årigt perspektiv. Köpenhamn: Museum Tusculanum Förlag, 2009.

Schön, Donald A., The Reflective Practitioner. How Professionals Think in Action. New York: Basic Books, 1983.

SOU (Swedish Governmental Investigations) 1926: 10.

Svensson, Daniel, interview with Bengt Saltin at Videnskabernes Hus, Copenhagen, February 13th, 2012.

Svensson, Daniel, interview with Per-Olof Åstrand at The Swedish School of Sport and Health Sciences, Stockholm, February 3d, 2012.

Söderberg, Benkt, Från gestalt till motor. Kroppsövningarnas medicinska modellskifte 1900-1940. English title: From Form to Motor. The Medicinal Model Shift in Exercise 1900-1940. Stockholm: Idrottshistoriska specialseminariet, Historiska institutionen, Stockholm university, 1998.

Söderberg, Benkt, Tre perspektiv på idrott och medicinvetenskap, 1900-1930. English title: Three perspectives on sports and medicinal science, 1900-1930. Stockholm: Idrottshistoriska specialseminariet, Historiska institutionen, Stockholm university, 1998.

Wrynn, Alison M., 'The Athlete in the Making: The Scientific Study of American Athletic Performance, 1920-1932' in Sport in History, issue 30:1, p. 121-137. Oxford: Routledge, 2010.

Yttergren, Leif, Träna är livet: träning, utbildning och vetenskap i svensk friidrott, 1888-1995. Malmö: idrottsforum.org, 2012.

Åstrand, Irma, 'Lactate Content in Sweat' in Acta Physiologica Scandinavica, 1963, issue 58, p. 359367. Stockholm: The Scandinavian Physiological Society, 1963. 
Åstrand, Per-Olof, Kondition och hälsa. Stockholm: Skandia, 1968.

Åstrand, Per-Olof, 'Fysiologiska institutionens tillkomst och utveckling' in Halldén, Olle (ed.), Festskrift vid GCI-GIH:s 175-årsjubileum. Stockholm: Gymnastik- och idrottshögskolan i Stockholm, 1988.

Åstrand, Per-Olof and Saltin, Bengt, 'Oxygen uptake during the first minutes of heavy muscular exercise' in Journal of Applied Physiology, 1961, vol. 16 issue 6, p. 971-976. The American Physiological Society, 1961.

Åstrand, Per-Olof and Saltin, Bengt, 'Maximal oxygen uptake in athletes' in Journal of Applied Physiology, 1967, vol. 23, issue 3, p. 353-358. The American Physiological Society, 1967. 